\title{
Preliminary Results of Betulinic Acid-Loaded Magnetoliposomes - a Potential Approach to Increase Therapeutic Efficacy in Melanoma
}

\begin{abstract}
CLAUDIA GEANINA FARCAS ${ }^{1,2}$, ELENA ALINA MOACA ${ }^{1 *}$, RAZVAN DRAGO I ${ }^{3 *}$, DELIA BERCEANU VADUVA ${ }^{3 *}$, IASMINA MARCOVICI ${ }^{1}$, CIPRIAN VALENTIN MIHALI', FELICIA LOGHIN²

${ }^{1}$ Victor Babes University of Medicine and Pharmacy Timisoara, Faculty of Pharmacy, 2 Eftimie Murgu Sq., 300041, Romania IIuliu Hatieganu University of Medicine and Pharmacy Cluj-Napoca, Faculty of Pharmacy, Dept of Toxicology, 8 Victor Babes Str., 400012, Cluj-Napoca, Romania

${ }^{3}$ Victor Babes University of Medicine and Pharmacy Timisoara, Faculty of Medicine, 2 Eftimie Murgu Sq., 300041, Romania ${ }^{4}$ Vasile Goldis Western University of Arad, Institute of Life Sciences, George Emil Palade Electron Microscopy Center, 86 Liviu Rebreanu Str., 310414, Romania

Magnetoliposomes were placed into the biomedical spotlight due to their unique structure, preserving also magnetic features valuable for biomedical applications. The present study provides a preliminary evidence of the cytotoxicity induced by betulinic acid-loaded magnetoliposomes ( $B A-F e, O @ L i p)$ on two melanoma cell lines - A375 and B164A5 cells and one healthy cell line - mice epidermis JB6 CI 41-5a cells, augmented by references to potential biomedical applications. BA-Fe $\mathrm{O}_{4} @ L$ Lip showed significant cytotoxicity on the melanoma cell lines, compared with the blank liposomal structures. In addition, the healthy cell line displayed good viability rate after exposure to $B A-\mathrm{Fe}_{3} \mathrm{O}_{4} @ L$ Lip.
\end{abstract}

Keywords: betulinic acid, thermosensitive magnetoliposomes, cytotoxicity, melanoma cells

Betulinic acid (BA) is a pentacyclic triterpene natural compound possessing a lupan structure [1,2] thathas been proved to exhibitmultiple therapeutic properties: selective antitumor activity, displaying minimal cytotoxic potential on healthy cells [3,4]; anti-HIV-1 (human immunodeficiency virus type-1) activity [5]; antimalarial and antiinflammatory effect [6,7], anti-angiogenic potential [8, 9], antibacterial and anthelmintic activity [6], augmented by its antioxidant capacity [10], being considered a compound with an important therapeutic potential.

Despite all these features, BA possesses a major inconvenience due to its low solubility in the biological hydrophilic medium, leading to poor bioavailability [11]. Derivatization of two key positions of the chemical structure of $\mathrm{BA}$, marked red in figure $1-\mathrm{C}_{3}$ hydroxyl, $\mathrm{C}_{28}$ carboxyl, has been shown to potentiate the cytotoxic effect of $B A$ and even increase its hydrophilicity, thus enhancing its bioavailability. However, the purification process of these derivatives is difficult to achieve [12].

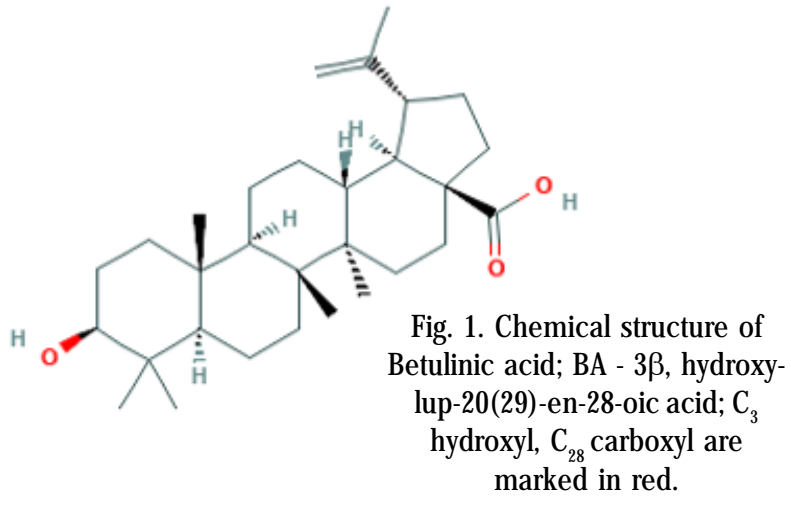

In the last years, several types of formulations have been developed to improve the bioavailability of $B A$, such as: BA nanoemulsion [9], incorporation of $B A$ into cyclodextrins [13], cocrystals formation of BA and vitamin C [14], incorporation of BA into liposomes [15], BA functionalized carbon nanotubes [16], thus this topic has become of great interest among researchers around the world.

Liposomes embedding nanoparticles with magnetic properties (MNPs) are generically entitled magnetoliposomes [17]. Due to superparamagnetic features, MNPs can be used for magnetically induced hyperthermia, as drug delivery tools, or as magnetic resonance imaging (MRI) agents [18], hence the magnetoliposome platform can also benefit from the aforementioned features [17]. Among all MNPs, the most commonly used structure is $\mathrm{Fe}_{3} \mathrm{O}_{4}$ - magnetite (part of the iron oxide magnetic nanoparticles group - IOMNPs) due to its biocompatibility, high saturation magnetization and good colloidal stability if the surface is properly coated [19]. The use of a coating agent is necessary because due to their large surface area to volume ratio, van der Walls forces and/or by application of an external magnetic field, IOMNPs can agglomerate leading to large cluster formation [20].

However, to the best of our knowledge, no study has so far reported the incorporation of BA within magnetoliposome structure. This new formulation would not only improve BA's bioavailability butcould offer new therapeutic approaches as an alternative to the classical chemotherapy, by merging BA therapeutic activity with the superparamagnetic behaviour of IOMNPs. In this study, $\mathrm{Fe}_{3} \mathrm{O}_{4}$ nanoparticles coated with citric acid $\left(\mathrm{Fe}_{3} \mathrm{O}_{4} @ \mathrm{CA}\right)$ were used for the synthesis of magnetoliposomes. Through the coating process, nanoparticles have acquired hydrophilicity and colloidal stability, possessing a hydrodynamic diameter of $101 \mathrm{~nm}$ (data not shown), thus overcoming undesirable effects that are characteristic of uncoated nanoparticles: agglomeration and rapid elimination by macrophages.

Herein, we present the development of a magnetoliposome structure that incorporates $B A$ into the phospholipid bilayer and $\mathrm{Fe}_{3} \mathrm{O}_{4} @ \mathrm{CA}$ into the aqueous core.

\footnotetext{
* email: alina.moaca@umft.ro,dragoi.razvan@umft.ro; deliaberceanu@yahoo.com
} 
The preliminary results of the effects induced by the magnetoliposome platform, as well as the blank liposomal structures, on two melanoma cell lines (murine melanoma B164A5 cells and human melanoma A375 cells) and one healthy cell line (mice epidermis J B6 Cl 41-5a cells) are also discussed.

The aim of the study is to provide basis information regarding development of smart multifunctional systems, such as magnetically-guided magnetoliposomes which can be controlled to reach the tumour site by applying an alternating magnetic field (AMF) followed by magnetically induced hyperthermia - able to alter the structure of liposomes, emerging BA triggered release.

\section{Experimental part}

Materials and methods

Reagents and cell lines

Betulinic acid (Lot \# BCBW 1969), L- $\alpha$-Phosphatidylcoline from soybean (Lot \# SLBT0172), Cholesterol from sheep wool and Polyethylene glycol 2000 (PEG-2000) were supplied from Sigma-Aldrich (Munich, Germany). Cell culture media, high glucose Dulbecco's Modified Eagle's Medium (DMEM) and Eagle's Minimum Essential Medium (EMEM) were purchased from ATCC.

The cell lines used in this study JB6 Cl 41-5a $\left(\right.$ ATCC $^{\circledR}$ CRL-2010) and A375 (ATCC ${ }^{\circledR}$ CRL-1619) were acquired from American Type Culture Collection (ATCC) and B164A5 vial (code 94042254) was purchased from Sigma-Aldrich (Munich, Germany). All the cell lines were maintained in standard conditions (liquid nitrogen) until the experiments begun.

Preparation of magnetic iron oxide nanoparticles (IOMNPS)

The IOMNPs were synthesized using the combustion method [21] using iron nitrate nonahydrate $\left(\mathrm{Fe}\left(\mathrm{NO}_{3}\right) \cdot 9 \mathrm{H}_{2} \mathrm{O}\right.$ - as the oxidizing agent and citric acid monohydrated $\mathrm{C}_{6} \mathrm{H}_{8} \mathrm{O}_{7} \cdot \mathrm{H}_{2} \mathrm{O}$ - as reducing agent. The obtained powder was hand grinded, washed with hot distilled water $\left(60-70^{\circ} \mathrm{C}\right)$ and dried.The dried $\mathrm{Fe}_{3} \mathrm{O}_{4}$ nanoparticles were coated with citric acid (CA) and then dispersed in water at basic $\mathrm{pH}$ thus obtained the biocompatible colloidal suspension.

Preparation of betulinic acid-loaded magnetoliposomes Betulinic acid-loaded magnetoliposomes (BA$\mathrm{Fe}_{3} \mathrm{O}_{\mathrm{A}} @ \mathrm{Lip}$ ) were obtained by preparing a blank liposomal solution (Lip) of $0.1 \mathrm{mM}$ lipid mixture using the lipid film hydration method [22]. The lipid mixture was composed of hydrogenated soybean phosphatidylcholine (HSPC), cholesterol and PEG-2000 in a molar ratio 90:10:0.4 and dissolved in chloroform by magnetic stirring at $40^{\circ} \mathrm{C}$ for $1 \mathrm{~h}$, followed by drying at oven $\left(40^{\circ} \mathrm{C}\right)$ overnight. Afterwards, the lipid film was hydrated with ultrapure water containing $(\mathrm{NH})_{2} \mathrm{SO}$. For the synthesis of blank magnetoliposomes ( $\left.\mathrm{Fe}_{3} \mathrm{O}_{4} @ \mathrm{Lip}\right)$ an amount of filtered liposomal suspension (Lip) was magnetic stirring at $45^{\circ} \mathrm{C}$ and the biocompatible colloidal suspension based on iron oxide magnetic nanoparticles ( $\mathrm{Fe}_{3} \mathrm{O} @ \mathrm{CA}$ ) was dropwise added. Total lipid to magnetic colloidalal suspension ratio was 4:1, according to the study of Kulshrestha and co-workers [23]. Finally, BA- $\mathrm{Fe}_{3} \mathrm{O}_{4} @$ Lip sample was obtained by mixing an amount of liposomal suspension (Lip) with a chloroform solution based on betulinic acid (10:1 m/m). After that, the colloidal suspension of $\mathrm{Fe}_{2} \mathrm{O}_{4} @ \mathrm{CA}$ was dropwise added (4:1 v/v) [23]. All liposomal suspensions were shocked for 1 h using a Q Sonica ultrasound device, at $50 \%$ amplitude. After sonication, samples were centrifuged at $4^{\circ} \mathrm{C}$ for $10 \mathrm{~min}$ at $6000 \mathrm{rpm}$ for 5 times, re-suspended in ultrapure water and shocked for $10 \mathrm{~min}$ at $50 \%$ amplitude. After that, the liposomal suspensions were filtered once through a hydrophilic membrane of $220 \mathrm{~nm}$, and stored at $4^{\circ} \mathrm{C}$ until further use.

No instability signs (flocculation/agglomeration) were observed for almost one month if stored in appropriate conditions $\left(4^{\circ} \mathrm{C}\right)$.

\section{Characterization of BA- $\mathrm{Fe}_{3} \mathrm{O}_{4} @ L$ Lip \\ Thermal analysis}

To determine the phase transition temperature of BA$\mathrm{Fe}_{3} \mathrm{O} @$ @ip the sample was placed in aluminum crucibles under artificial air flow of $20 \mathrm{~mL} / \mathrm{min}$, and thermally scanned from $25-1000{ }^{\circ} \mathrm{C}$ at a heating rate of $10^{\circ} \mathrm{C} / \mathrm{min}$ using a TG/DSC thermal analyzer (Netzsch STA 449 C instrument (Selb, Germany).

\section{Structural characterization}

Scanning electron microscopy (SEM) was employed to evaluate the morphology of $\mathrm{BA}-\mathrm{Fe}_{3} \mathrm{O}_{4} @ \mathrm{Lip}$ and the energy dispersive X-ray analysis (EDAX) was used in order to obtain the elemental composition of the sample. SEM-EDAX analysis was carried out with EDX detection on scanning electron microscope (SEM), using an EDAX detector (ZAF Quantification-Standardless, Element Normalized) with FEI Quanta 250 microscope (Eindhoven, Holland).

Cell viability evaluation by the means of AlamarBlue $(A B)$ assay

Assessment of the cytotoxic potential of test samples was performed as previously described [24]. 1x106 cells/ well were seeded in 96-well plates and incubated overnight. The next day, the old medium was replaced with a fresh one containing the test compounds ( $\mathrm{Lip}, \mathrm{Fe}_{3} \mathrm{O} @ \mathrm{Lip}$, $\mathrm{BA}-\mathrm{Fe}_{3} \mathrm{O}_{4} @ \mathrm{Lip}$ and $\mathrm{BA}$ ) to a final concentration equivalent to 5 and $25 \mu \mathrm{M}$ BA. BA dissolved in DMSO was also tested and was used as a positive control. After a period of 24/48 $\mathrm{h}$ of stimulation, $20 \mathrm{uL}$ AlamarBlue solution (AB - $0.01 \%$ ) was added in each well and incubated for $3 h$. In the final step, the absorbance of the wells was determined at 570 $\mathrm{nm}$ and $600 \mathrm{~nm}$ wavelengths, with a microplate reader (xMark ${ }^{\mathrm{TM}}$ Microplate, Biorad).

\section{Cell morphology assessment}

The morphological alterations induced by test samples on the three cell lines (JB6 Cl 41-5a, A375, B164A5) were assessed by taking pictures of the cells stimulated with the test compounds, at different intervals of time with an inverted Olympus IX73 microscope documented with an integrated DP74 camera (Olympus, Tokyo, Japan). The most severe morphological changes were observed $24 \mathrm{~h}$ post-stimulation and are presented in fig. 5-7.

\section{Statistical analysis}

The statistical program used in this study was GraphPad Prism 5. Bar graphs are expressed as the mean values \pm SD of three independent experiments. One-way ANOVA test followed by Tukey's post-test were employed to determine the statistical differences between experimental and control groups ( $*<<0.05$; $* * p<0.01$; $* * * \quad p<0.001$ )

\section{Results and discussion}

\section{Physio-chemical characterization of BA-Fe, $\mathrm{O} @$ Lip}

Thermogravimetric (TG) and differential scanning calorimetry (DSC)

Thermal analysis and phase transition temperature of $\mathrm{BA}-\mathrm{Fe}_{3} \mathrm{O}_{4} @ \mathrm{Lip}$ are depicted in figure 2. From the graph, it

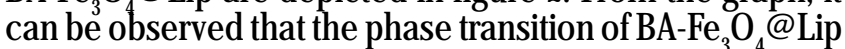
from gel to liquid crystalline occurred at $39.437^{\circ} \mathrm{C}$. This temperature could be achieved in vitro or in vivo by using 

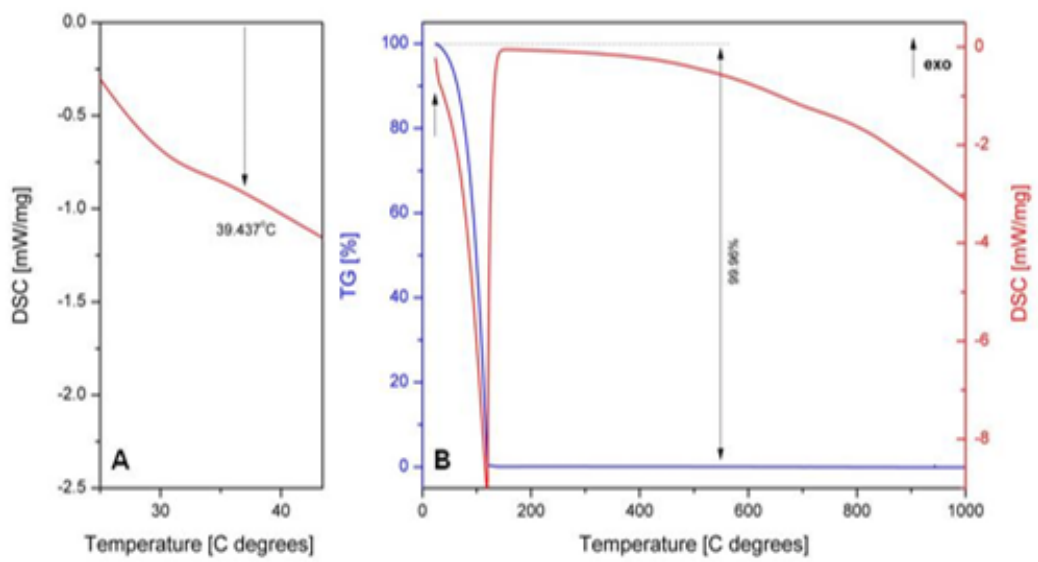

\begin{tabular}{|c|c|c|c|c|c|c|}
\hline Element & Wt $\%$ & At $\%$ & K-Ratio & Z & A & F \\
\hline $\mathrm{C} \mathrm{k}$ & 49.55 & 56.67 & 0.2153 & 1.0077 & 0.4311 & 1.0004 \\
\hline $\mathrm{Nk}$ & 9.87 & 9.68 & 0.0115 & 1.0003 & 0.1164 & 1.0007 \\
\hline $\mathrm{Ok}$ & 37.82 & 32.47 & 0.0551 & 0.9936 & 0.1466 & 1.0000 \\
\hline $\mathrm{Sk}$ & 0.74 & 0.33 & 0.0053 & 0.9285 & 0.7667 & 1.0022 \\
\hline Fe k & 1.91 & 0.82 & 0.0160 & 0.9535 & 0.8772 & 1.0000 \\
\hline Total & 0.11 & 0.03 & 0.0010 & 0.8581 & 1.0872 & 1.0000 \\
\hline
\end{tabular}

Fig. 2. A - Phase transition temperature of BA-Fe $\mathrm{O}_{4} @ \mathrm{Lip}, \mathbf{B}$ - TG-DSC curves of $\mathrm{BA}-\mathrm{Fe}_{3} \mathrm{O}_{4} @ \mathrm{Lip}$

Tabel 1

ELEMENTAL COMPOSITION OF BA-Fe ${ }_{3} \mathrm{O}_{4} @ L$ Lip

$\mathrm{Fe}_{2} \mathrm{O}$ nanoparticles as tools for inducing mild hyperthermia, following exposure to an external magnetic field due to magnetic hysteresis loss [18]. In the phase transition, the release of $B A$ from the liposome nanosphere may emerge. Thus, it could be stated that the release of BA could be thermally controlled.

\section{Structural characterization}

The EDAX analysis showed that only C, O, N, P, S and Fe were present in the sample (table 1). The resulting chemical species in EDAX analysis were expressed in weightpercent

By scanning electron microscopy -SEM (fig. 3) it has been established the details regarding the morphology and ultrastructure of the BA-Fe $\mathrm{O} @$ @ip.

From figure 3 , it can be observed that the structure of BA- $\mathrm{Fe}_{3} \mathrm{O}_{4} @$ Lip containing $\mathrm{Fe}_{3} \mathrm{O}_{4}$ nanoparticles shows spherical structures without any inner water pool.

Cell viability assessment by the means of AlamarBlue assay As shown in figure 4, the viability of the healthy J B6 Cl 41-5a cells exposed to the lowest concentration of the liposomal structures $(5 \mu \mathrm{M})$ was not significantly affected, (Wt \%) or atomic percent (At \%).

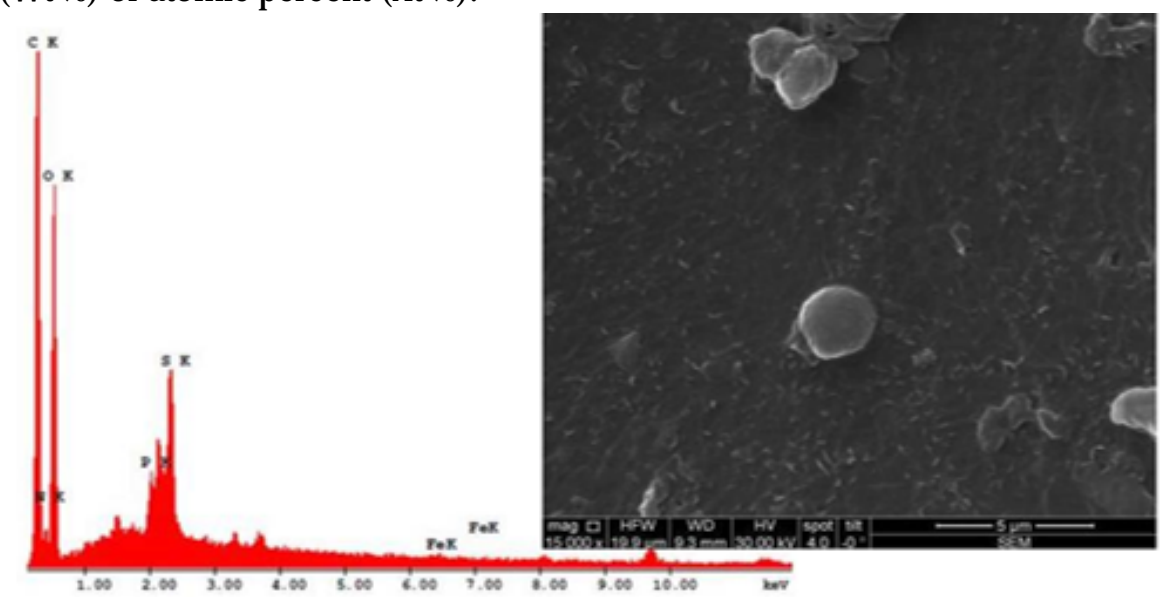

Fig. 3. SEM-EDAX analysis of $\mathrm{BA}-\mathrm{Fe}_{3} \mathrm{O}_{4} @ \mathrm{Lip}$.

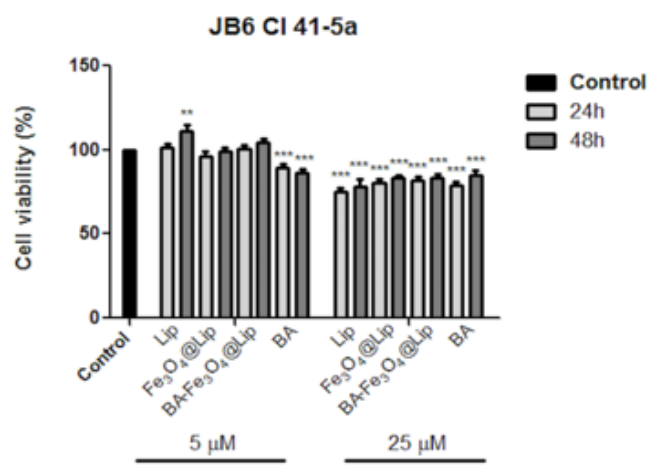

Fig. 4. Cell viability of mice epidermis J B6 Cl 41-5a cells after stimulation with test samples ( 5 and $25 \mu \mathrm{M}$ ). The data are presented as cell viability percentage normalized to control cells (no stimulation) 
BA expressing the most damaging effect. However, the highest concentration of compounds $(25 \mu \mathrm{M})$ induced a reduction of viable $\mathrm{J}$ B6Cl 41-5a cell population, showing a viability percentage around $75-83 \%$. After $48 \mathrm{~h}$, all samples induced a slight increase (about 4-5\%) of J B6 Cl 41-5a viability rate, comparative with the cell viability rate expressed after $24 \mathrm{~h}$ post-stimulation.

The blank liposomal structures (Lip, $\mathrm{Fe}_{3} \mathrm{O}_{4} @$ Lip) manifested cell viability above $60 \%$ in the case of both cell lines, after treatment with the highest concentration $(25 \mu \mathrm{M})$. The effect induced by test compounds respected almost the same tendency of cell viability decrease on both melanoma cell lines (B164A5 and A375), yet A375 cells seemed to be more sensitive. Present data showed

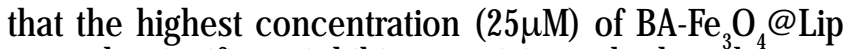
caused a significant inhibitory activity on both melanoma cell lines, displaying a viability rate of $24 \%$ on B164A5 cells versus $7.80 \%$ viability percentage in the case of $A 375$ cells, after $24 \mathrm{~h}$ post-stimulation. How ever, both cell lines (A375, B164A5) manifested a slight cell viability grow th after 48h, B164A5 cells expressing a viability percentage of $38 \%$, compared to a viability rate of $31.5 \%$ expressed by $A 375$ cells. The trend of cell viability growth after $48 \mathrm{~h}$ of stimulation was observed by almost all test samples, except BA which exhibited a higher cytotoxic activity after $48 \mathrm{~h}$, compared with the one recorded after $24 \mathrm{~h}$ posttreatment (fig. 5).
Thus, we assume that the cytotoxic effect induced by $\mathrm{BA}-\mathrm{Fe}_{3} \mathrm{O}_{4} @$ Lip may be due to $\mathrm{BA}$ embedded in the magnetoliposome structure. Association of the BA wellknown cytotoxic potential with the applications IOMNPs in biotechnology (hyperthermia, drug controlled release) can lead to a synergistic anti-tumor activity.

\section{Cell morphology after treatment with test samples}

The most severe morphological alterations of the test cell lines (J B6 Cl 41-5a, B164A5, A375) were recorded 24h post-stimulation and are depicted in figures 6-8.

The healthy mice epidermis J $\mathrm{B} 6 \mathrm{Cl}$ 41-5a cells exposed to the lowest concentration of liposomal samples ( $5 \mathrm{mM}$ ) presented normal morphological aspects, epithelial-like with a confluence above $90 \%$. How ever, the cells treated with $\mathrm{BA}$ at the same concentration of $5 \mathrm{M}$ exhibited slight morphological alterations, indicated by the red arrows in figure 6 .

The cells stimulated with test samples at the highest tested concentration (25 mM) induced some morphological changes, but still no more substantial than those induced by the same concentration of BA, used as positive control.

As shown in figure 7 and figure 8 , both melanoma cell lines (B164A5 and A375 cells) manifested no altered morphological aspects after treatment with the lowest
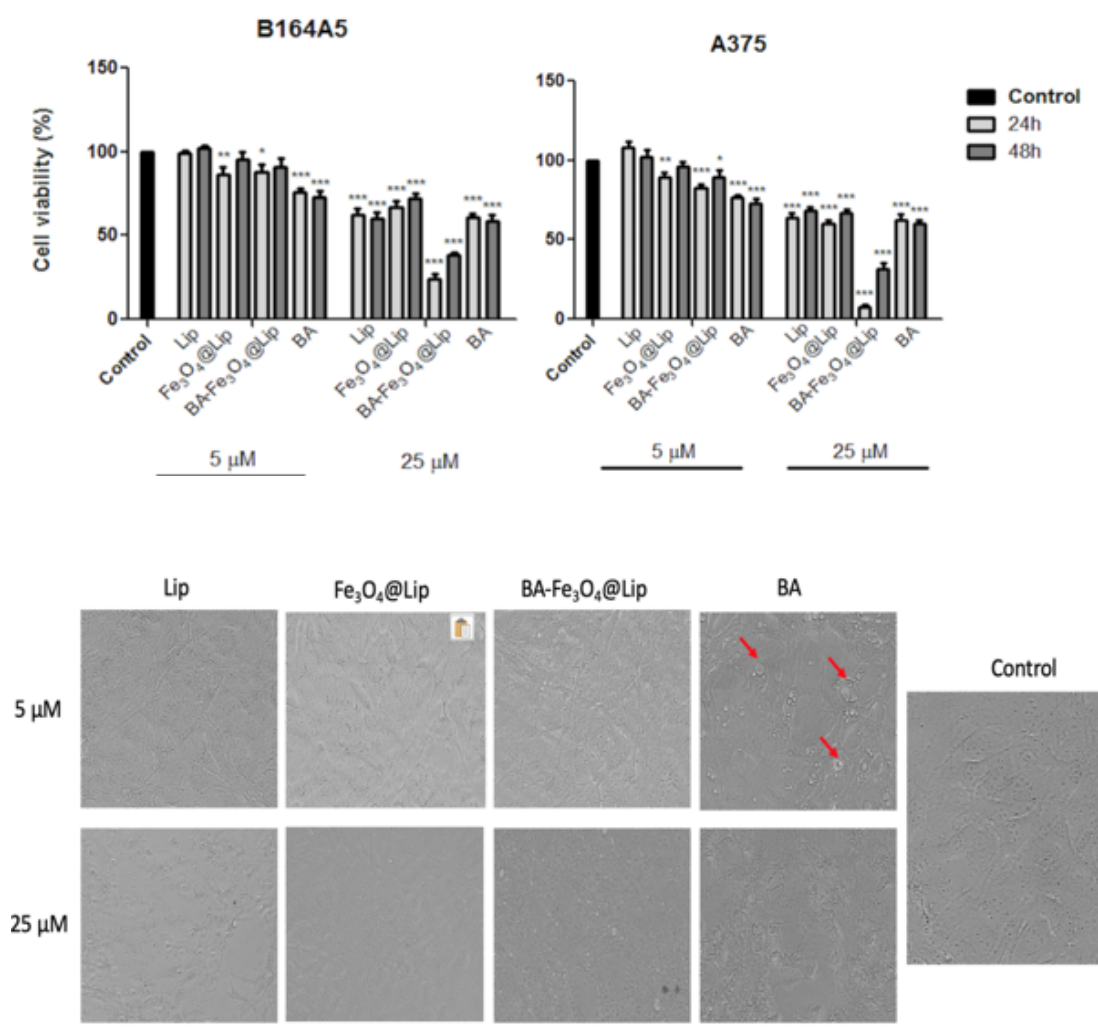

Lip

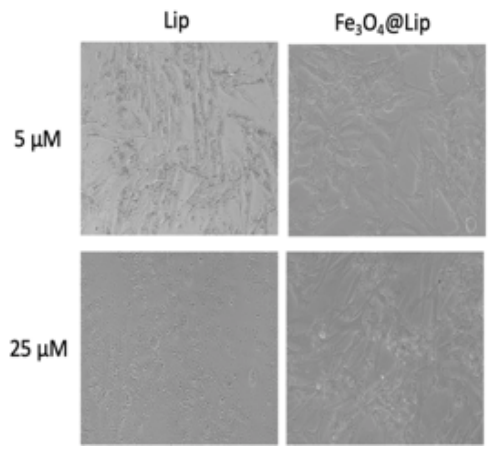

BA- $\mathrm{Fe}_{3} \mathrm{O}_{4} @$ Lip

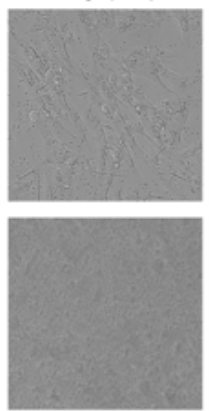

BA

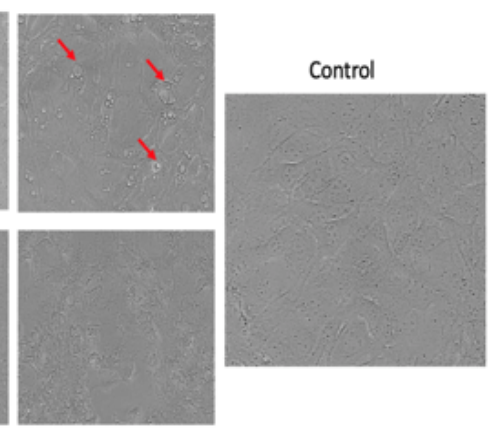

BA

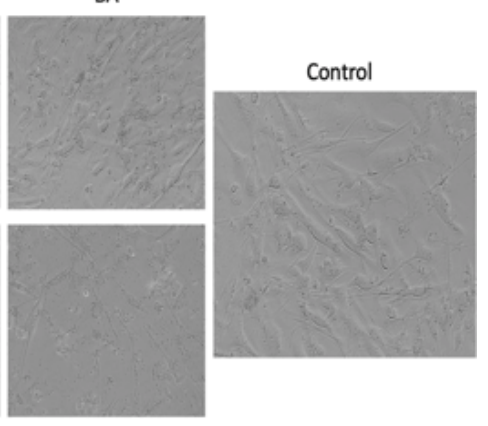

Fig. 5. Cell viability of murine melanoma B164A5 cells and human melanoma -A375 cells after stimulation with test samples ( 5 and $25 \mu \mathrm{M})$. Bar graphs are expressed as cell viability percentage normalized to control cells (no stimulation).

Fig. 6. Morphological aspects of mice epidermis JB6 Cl 41-5a cells stimulated with test samples ( 5 and $25 \mu \mathrm{M}$ ), $24 \mathrm{~h}$ post-treatment

Fig. 7. Morphological aspects of murine melanoma - B164A5 cells stimulated with test samples ( 5 and $25 \mu \mathrm{M}), 24 \mathrm{~h}$ posttreatment. 


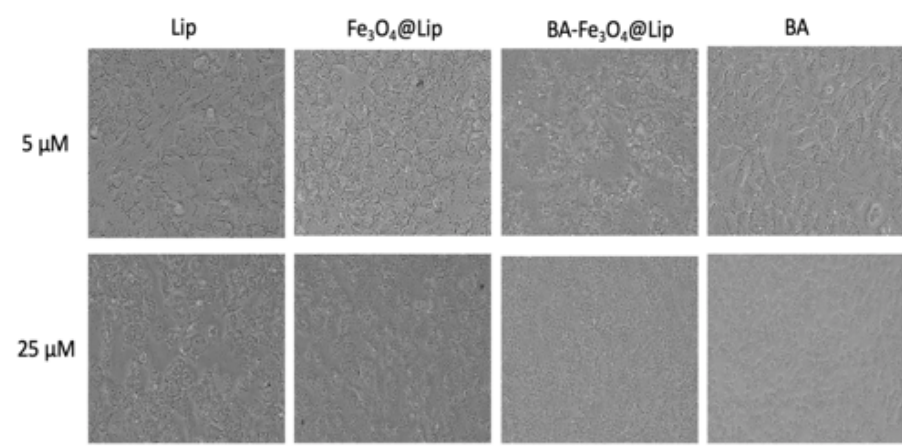

Control

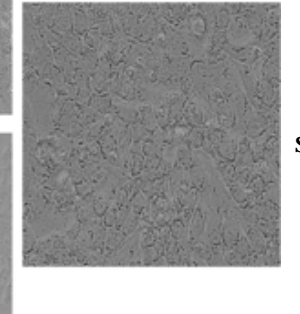

Fig. 8. Morphological aspects of human melanoma -A375 cells stimulated with test samples ( 5 and $25 \mu \mathrm{M}$ ), $24 \mathrm{~h}$ post-treatment.

concentration ( $5 \mu \mathrm{M})$ of test compounds. Increasing the concentration at $25 \mu \mathrm{M}$, severe morphological changes were observed, especially after treatment with the compound of interest (BA-Fe, 0 @Lip). In this case, the cytotoxic activity manifested by the highest concentration of test samples was not exceeded by the effect of BA treatment. Still, human melanoma A375 cells seemed more sensitive, a lot of apoptotic cells being observed after treatment with $\mathrm{Fe}_{3} \mathrm{O}_{4} @ \mathrm{Lip}$ and $\mathrm{BA}$, data supported by cell viability assessment.

A similar magnetoliposome system was also developed by Kulshrestha and collaborators, having paclitaxel as active substance and citric acid coated $\mathrm{Fe}_{3} \mathrm{O}$ NPs, as a magnetic compound. The magnetoliposomal platform expressed good cytotoxic activity on HeLa cells and great potential for drug delivery application and hyperthermia [23]. Clares and co-workers reported nanosized 5fluorouracil-loaded magnetoliposomes with good in vitro compatibility and features for creating hyperthermic conditions to release 5-fluorouracil from the thermosensitive magnetoliposome structure [25]. Beside hyperthermia and drug controlled release, recent studies reported the efficacy of magnetoliposomes as contrast agents: in a rat model of liver ischemia-reperfusion [26] or in a diabetic rat model for labeling pancreatic islets [27].

In a comprehensive literature review, Allen and Cullis explained the importance of including cholesterol in the liposome structure, considering that this compound improves the phospholipid bilayer's stiffness, thereby reducing drug leakage from the liposomes [28]. Moreover, the same study presented the advantages of using ammonium sulfate for obtaining remote loading of drugs within liposomes, by transforming the drugs in weak bases or weak base prodrugs. Other studies discussed the importance of using PEGylated liposomes to enhance drug encapsulation efficiency [29], along with a better stability [30]. The synthesis process employed in this study respected all the aforementioned details described in the literature to achieve an improved formula of magnetoliposomes.

\section{Conclusions}

The experiments conducted in this study provide basic evidence of the massive potential of magnetoliposomes as thermally controlled structures, displaying selective cytotoxicity on murine melanoma B164A5 cells and human melanoma A375 cells, showing slight inhibitory activity on mice epidermis JB6 Cl 41-5a cells viability. The magnetoliposome platform may offer a multitude of multifunctional biomedical applications, such as combining hyperthermia with drug controlled release. Nevertheless, in vitro and in vivo experiments should continue to be performed.

Acknowledgment: This study was financially supported from a grant offered by Iuliu Hatieganu University of Medicine and Pharmacy, Cluj-
Napoca, Romania for doctoral research project, awarded by Claudia Farcas, contractno 1300/23/13.01.2017; 3066/17/01.02.2018.

\section{References}

1.GHEORGHEOSU, D., JUNG, M., OREN, B., SCHMID, T., DEHELEAN, C., MUNTEAN, D., BRUNE, B. Betulinic acid suppresses NGAL-induced epithelial-to-mesenchymal transition in melanoma. Biol. Chem., 394(6), 2013, p. 773-781. DOI 10.1515/hsz-2013-0106

2. FULDA, S. Betulinic acid: A natural product with anticancer activity. Mol. Nutr. Food Res., 53, 2009, p. 140 - 146. DOI 10.1002/mnfr.200700491 3. MULLAUER, F.B., KESSLER J.H., MEDEMA J.P. Betulinic acid, a natural compound with potent anticancer effects. Anti-Cancer Drugs, 21, 2010, p. 215-227. DOI: 10.1097/CAD.0b013e3283357c62.

4. ZUCO, V., SUPINO, R., RIGHETTI, S.C., CLERIS, L., MARCHESI, E., CARLO, G-P., FORMELLI, F. Selective cytotoxicity of betulinic acid on tumor cell lines, but not on normal cells. Cancer Letters, 175, 2002, p. 17-25. https://doi.org/10.1016/S0304-3835(01)00718-2

5. CICHEWICZ, R.H., KOUZI, S.A. Chemistry, Biological Activity, and Chemotherapeutic Potential of Betulinic Acid for the Prevention and Treatment of Cancer and HIV Infection. Med. Res. Rev., 24 (1), 2004, p. $90-114$, . DOI 10.1002/med.10053

6. YOGEESWARI, P., SRIRAM, D. Betulinic acid and its derivatives: a review on their biological properties. Curr. Med. Chem., 12(6), 2005, p. 657-66.

7. MOGHADDAM, M.G, AHMAD, F.B.H., SAMZADEH-KERMANI, A. Biological Activity of Betulinic Acid: A Review. Pharmacology \& Pharmacy, 3, 2012, p. 119-123. http://dx.doi.org/10.4236/pp.2012.32018. 8. MUKHERJEE, R., JAGGI, M., RAJENDRAN, P., SIDDIQUI, M.J.A., SRIVASTAVA, S.K., VARDHAN, A., BURMAN, A.C. Betulinic acid and its derivatives as anti-angiogenic agents. Bioorg. Med. Chem. Lett., 14, 2004, p. 2181-2184. doi:10.1016/j.bmcl.2004.02.044.

9.DEHELEAN, C.A., FEFLEA, S., GANTA, S., AMIJI, M. Antiangiogenic effects of betulinic acid administered in nanoemulsion formulation using chlorioallantoic membrane assay. J. Biomed. Nanotechnol., 7(2), 2011, p. 317-24.

10. ZHU, L., YI, X., ZHAO, J., YUAN, Z., WEN, L., POZNIAK, B., OBMINSKA-MRUKOWICZ, B., TIAN, Y., TAN, Z., WU, J., YI, J. Betulinic acid attenuates dexamethasone-induced oxidative damage through the JNK-P38 MAPK signaling pathway in mice. Biomed. Pharmacother. 103, 2018, p. 499-508. doi: 10.1016/j.biopha.2018.04.073. 11. WANG, H.M., 'OICA, C.M., WENZ, G. A Comparison Investigation on the Solubilization of Betulin and Betulinic Acid in Cyclodextrin Derivatives. Nat. Prod. Commun.,7, 2012, p. 289-291.

12. PERIASAMY, G., TEKETELEW, G., GEBRELIBANOS, M., SINTAYEHU, B., GEBREHIW OT, M., KARIM, A., GEREMEDHIN, G. Betulinic acid and its derivatives as anti-cancer agent:A review. Arch. Appl. Sci. Res., 6 , 2014, p. 47-5.

13. SOICA, C., DANCIU, C., SAVOIU-BALINT, G., BORCAN, F., AMBRUS, R., ZUPKO, I., BOJIN, F., CORICOVAC, D., CIURLEA, S., AVRAM, S., DEHELEAN, C.A., OLARIU, T., MATUSZ, P. Betulinic acid in complex with a gamma-cyclodextrin derivative decreases proliferation and in vivo tumor development of nonmetastatic and metastatic B164A5 cells. Int. J. Mol. Sci., 15, 2014, p. 8235-55. doi: 10.3390/ijms15058235.

14. NICOLOV, M., GHIULAI, R.M., VOICU, M., MIOC, M., DUSE, A.O., ROMAN, R., AMBRUS, R., ZUPKO, I,, MOACA, E.A., CORICOVAC, D.E., FARCAS, C., RACOVICEANU, R.M., DANCIU, 
C., DEHELEAN, C.A., SOICA, C. Cocrystal Formation Cocrystal Formation Synthesis, Physico-Chemical Assessment, Antioxidant, and Antiproliferative Activity. Front. Chem., 7, 2019, p. 92. doi: 10.3389/fchem.2019.00092.

15. LIU, Y., GAO, D., ZHANG, X., LIU, Z., DAI, K., JI, B., WANG, Q., LUO L., Antitumor drug effect of betulinic acid mediated by polyethylene glycol modified liposomes. Mater. Sci. Eng. C. Mater. Biol. Appl., 64, 20 16, p. 124-132. doi: 10.1016/j. msec .2016.03.080.

16. TAN, J.M., KARTHIVASHAN, G., ABD GANI, S., FAKURAZI, S., HUSSEIN, M.Z. Biocompatiblepolymers coated on carboxylated nanotubes functionalized with betulinic acid for effective drug delivery. J. Mater. Sci. Mater. Med., 27, 2016. doi: 10.1007/s10856015-5635-8.

17. SANTHOSH, P.B., DRASLER, B., DROBNE, D., KREFT, M.E., KRALJ, S., MAKOVEC, D., ULRIH, N.P., Effect of superparamagnetic iron oxide nanoparticles on fluidity and phase transition of phosphatidylcholine liposomal

membranes. Int. J. Nanomedicine., 10, 2015, p 6089-103. doi: 10.2147/ IJ N.S89679

18.GUPTA,A.K., GUPTA,M.Synthesis and surface engineering of iron oxide nanoparticles for biomedical applications. Biomaterials., 26, 2005, p. 3995-4021.

19 MOACA, E.A., CORICOVAC, E.D., SOICA, C.D., PINZARU, I.A., PACURARIU, C.S., DEHELEAN C.A. Iron Ores and Iron Oxide Materials. Preclinical Aspects on Magnetic Iron Oxide Nanoparticles and Their Interventions as Anticancer Agents: Enucleation, Apoptosis and Other Mechanism. IntechOpen, Edited by Volodymyr Shatokha, London, 2018, p. 229-247

20. MAHMOUDI, M., SANT, S., WANG, B., LAURENT, S., SEN, T. Superparamagnetic ironoxide nanoparticles (SPIONS): development, surface modification and applications in chemotherapy. Adv. Drug. Deliv. Rev., 63, 2011, p 24-46. doi: 10.1016/j.addr.2010.05.006.

21. IANOS, R., TACULESCU A., PACURARIU, C., LAZAU, I. Solution Combustion Synthesis and Characterization of Magnetite, $\mathrm{Fe}_{3} \mathrm{O}_{4^{\prime}}$ Nanopowders. J. Am. Ceram. Soc., 2012, p 1-5.

22. HE, Y., ZHANG, L., ZHU, D., SONG, C. Design of multifunctional magnetic iron oxide nanoparticles/mitoxantrone-loaded liposomes for both magnetic resonance imaging and targeted cancer therapy. Int. J. Nanomedicine., 9, 2014, p 4055-4066.
23. KULSHRESTHA, P., GOGOI, M., BAHADUR, D., BANERJEE, R. In gnetoliposomes for combined chemotherapy and hyperthermia. Colloids Surf. B. Biointerfaces., 96, 2012, p. 1-7.

24. MOACA, E.A., FARCAS, C., GHITU, A., CORICOVAC, D., POPOVICI, R.,CARABA-MEITA, N.L., ARDELEAN, F., ANTAL, D.S., DEHELEAN, C., AVRAM,

A Comparative Study of Melissa officinalis Leaves and Stems Ethanolic Extracts in terms ofAntioxidant, Cytotoxic, and Antiproliferative Potential. Evid. Based. Complement. Alternat. Med., 2018. doi: 10.1155/2018/7860456

25. CLARES, B., BIEDMA-ORTIZ, R.A., SAìEZ-FERNAiNNDEZ, E.,. PRADOS, J.C., MELGUIZO, C., CABEZA, L., ORTIZ, R., ARIAS, J.L. Nano-engineering of 5-fluorouracil-loaded magnetoliposomes for combined hyperthermia and chemotherapy against colon cancer. Eur. J. Pharm. Biopharm., 85, 2013, p. 329-338. https://doi.org/10.1016/ j.ejpb.2013.01.028

26. MARTINS, M.B., CORVO, M.L., MARCELINO, P., MARINHO, H.S., FEIO,G., CARVALHO, A. New long circulatig circulating magnetoliposomes as contrast agents for detection of ischemia-reperfusion injuries by MRI. Nanomedicine. 10, 2014, p. 207-14. doi: 10.1016/j.nano.2013.06.008.

27. GARCIA RIBEIRO R.S., GYSEMANS, C., DA CUNHA, J.P.M.C.M., MANSHIAN, B.B., JIRAK, D., KRIZ, J., GALLO, J, BANOBRE-LOPEZ, M., STRUYS, T., DE CUYPER, M., MATHIEU, C., SOENEN, S.J., GSELL, W., HIMMELREICH, U. Magnetoliposomes as Contrast Agents for Longitudinal in vivo Assessment of Transplanted Pancreatic Islets in a Diabetic Rat Model. Sci Rep., 8, 2018. doi: 10.1038/ s41598-018-29136-9

28. ALLEN, T.M., CULLIS, P.R. Liposomal drug delivery systems: from concept to clinical applications. Adv. Drug. Deliv. Rev., 65, 2013, p. 36-48. doi: 10.1016/j.addr.2012.09.037.

29. ZHAO, T., LIU, Y., GAO , Z., GAO, D., LI, N., BIAN, Y., DAI, K., LIU, Z. Self-assembly and cytotoxicity study of PEG-modified ursolic acid liposomes. Mater. Sci. Eng. C. Mater. Biol. Appl., 53, 2015, p 196-203. doi: 10.1016/j.msec.2015.04.022.

30. GAO, D., TANG, S., TONG, Q. Oleanolic acid liposomes with polyethylene glycol modification: promising antitumor drug delivery. Int. J. Nanomedicine., 7, 2012, p 3517-26. doi: 10.2147/IJ N.S31725.

Manuscript received: 11.05 .2019 